\title{
The Effects of Lactic Acid Bacteria and Enzyme Mixture Inoculants on Silage Fermentation Characteristics and Feed Values of Silage Prepared from Alfalfa Harvested at Different Maturities ${ }^{\#}$
}

\author{
Berrin Okuyucu, ${ }^{1, a, *}$, Selma Büyükkılıç Beyzi ${ }^{2, b}$, Mehmet Levent Özdüven,c \\ ${ }^{1}$ Department of Animal Science, Faculty of Agriculture, Tekirdă̆ Namık Kemal University, 59030 Tekirdă̆, Turkey \\ ${ }^{2}$ Department of Animal Science, Seyrani Faculty of Agriculture, Erciyes University, 38039 Kayseri, Turkey \\ *Corresponding author \\ ART ICLE INFO \\ A B S T R A C T \\ ${ }^{\#}$ This study was produced from a part \\ of the master's thesis. \\ Research Article \\ This study was carried out to determine the effects of lactic acid bacteria+ enzyme (LAB+E) \\ inoculants on the fermentation characteristics and feed values of silages prepared from alfalfa \\ harvested at three maturity stages. Alfalfa was harvested at the early, middle and late flowering \\ stages. Sil-All (Alltech, UK) were used as LAB+E inoculants. Inoculants were applied to the \\ silages at the rates of $1 \times 10^{5}, 5 \times 10^{5}$ and $1 \times 10^{6} \mathrm{cfu} / \mathrm{g}$ levels in 1 liter capacity plastic bags. The \\ bags were stored at $20 \pm 2^{\circ} \mathrm{C}$ under the laboratory conditions. Three bags from each group were \\ Received : 05/01/2021 \\ Accepted : 04/04/2021 \\ sampled for chemical and microbiological analyses on the $45^{\text {th }}$ day after ensiling. The results \\ showed that $\mathrm{LAB}+\mathrm{E}$ inoculants reduced $\mathrm{pH}$ values and ammonia-nitrogen content, whereas \\ increased lactic acid contents and lactobacillus count of alfalfa silages. High doses LAB $+\mathrm{E}$ \\ inoculant decreased neutral detergent fiber and acid detergent fiber content, increased in vitro \\ organic matter digestibility and metabolic energy of alfalfa silages. It has been demonstrated \\ Keywords: \\ that the most effective application dose of $\mathrm{LAB}+\mathrm{E}$ inoculant to improve fermentation and feed \\ Alfalfa \\ value of alfalfa silage was $1 \times 10^{6} \mathrm{cfu} / \mathrm{g}$, but $1 \times 10^{5}$ and $5 \times 10^{5} \mathrm{cfu} / \mathrm{g}$ level can also be considered \\ Fermentation \\ as effective dose. \\ Lactic acid bacteria \\ Aerobic stability \\ Feed value \\ Türk Tarım - Gıda Bilim ve Teknoloji Dergisi, 9(6): 1062-1069, 2021

\section{Farklı Olgunluk Dönemlerinde Hasat Edilen Yonca Bitkisinden Hazırlanan Silajlarda Laktik Asit Bakterisi ve Enzim Karışım İnokulant İlavesinin Silaj Fermantasyon Özellikleri ve Yem Değeri Üzerindeki Etkileri}

\begin{tabular}{|c|c|}
\hline M A K A L E B İ L G İ S İ & Ö Z \\
\hline $\begin{array}{l}\text { Anahtar Kelimeler: } \\
\text { Yonca } \\
\text { Fermantasyon } \\
\text { Laktik asit bakteri } \\
\text { Aerobik stabilite } \\
\text { Yem değeri }\end{array}$ & $\begin{array}{l}\text { Bu çalışma, üç ayrı vejetasyon döneminde hasat edilen yonca bitkisine farklı düzeylerde laktik } \\
\text { asit bakteri+enzim (LAB+E) inokulantı ilavesinin silaj fermantasyon özellikleri ve yem değeri } \\
\text { üzerindeki etkilerinin saptanması amacıyla yürütülmüştür. Yonca bitkisi çiçeklenme başlangicı, } \\
\text { çiçeklenme ortası ve çiçeklenme sonu döneminde hasat edilmiştir. Laktik asit bakteri+enzim } \\
\text { karışımı inokulant kaynağ1 olarak Sil-All (Alltech, UK) kullanılmıştır. İnokulant, yonca } \\
\text { hasıllarına } 1 \times 10^{5}, 5 \times 10^{5} \text { ve } 1 \times 10^{6} \mathrm{kob} / \mathrm{g} \text { düzeyinde katılmışır. Kontrol ve katk1 maddeleri ile } \\
\text { muamele edilen yonca } 1 \text { litre hacimli polietilen torbalarda silolanmıştır. Torbalar laboratuvar } \\
\text { koşullarında } 20 \pm 2^{\circ} \mathrm{C} \text { sıcaklıkta depolanmışlardır. Silolamadan sonraki } 45 \text {. günde her gruptan } \\
\text { 3'er torba aç1larak silajlarda kimyasal ve mikrobiyolojik analizler yapılmıştır. Sonuç olarak, } \\
\text { LAB+E inokulantı silajların pH ve amonyak azotu içeriklerini azaltırken; laktik asit, asetik asit } \\
\text { içerikleri ve lactobacilli sayısını artırmıştır. Yüksek dozda LAB+E ilavesi silajların nötr } \\
\text { deterjanda çözünmeyen lif ve asit deterjanda çözünmeyen lif içeriğini azaltmış, in vitro organik } \\
\text { madde sindirilebilirliğini ve metabolik enerji değerlerini artırmıştır. Yoncanın LAB+E } \\
\text { inokulant ilave edilerek silolanmasının fermantasyon özellikleri ve yem değerini iyileştirdiği, } \\
\text { en etkili dozun } 1 \times 10^{6} \mathrm{kob} \text { g/kg olmakla birlikte, } 1 \times 10^{5} \mathrm{kob} \text { g/kg ve } 5 \times 10^{5} \mathrm{kob} / \mathrm{g} \text { dozlarında da } \\
\text { uygulanabileceği belirlenmiştir. }\end{array}$ \\
\hline
\end{tabular}




\section{Introduction}

Alfalfa (Medicago sativa L.) is a perennial herbaceous legume. Due to its high adaptability, high yields and high nutritional quality, alfalfa is one of the most important legume roughages in most of the countries in the World. As a major source of protein for livestock, it is a basic component in rations for ruminants and other domestic animals (Radovic et al., 2009). It is cultivated in more than 80 countries in an area exceeding 35 million ha (Zubair et al., 2017). Alfalfa is rather fed to animals in dried form (Canbolat 2013). However, a significant loss of nutrients occurs due to mechanical treatments made during drying and storage (Oktay et al., 1990, Çiftçi et al., 2005, Acar and Bostan 2016). Alfalfa is generally utilized as silage particularly in rainy areas where sufficient drying is not possible (Çerçi 1996, Oten et al., 2016). It is hard to make good quality silage from the alfalfa due to its high buffering capacity and crude protein (CP) levels, lower dry matter (DM) and water-soluble carbohydrate (WSC) content. Therefore, it is necessary to use bacterial inoculants as additive for ensiling alfalfa which are rich in protein and low content of WSCs (Filya 2000). Bacterial inoculants in silage production are defined as products containing lactic acid bacteria $(\mathrm{LAB})$ or bacterial groups at a concentration level that encourages lactic acid (LA) fermentation. LAB, which is used as inoculant, prevents the development of butyric acid (BA) bacteria as a result of increasing acidity (approx. pH: 4) by accelerating LA fermentation in silage. However, since there is not enough WSC during the silage of the alfalfa, LAB cannot proliferate sufficiently, and as a result there is not enough LA production. Thus, LAB inoculants can be used as a silage additive in the form of a mixture of starch-degrading enzyme such as amylase and cell wall degrading enzymes (E), especially cellulase, hemicellulase and pectinase. Indeed, $E$ which are used in conjunction with $\mathrm{LAB}$, while enhancing silage fermentation by releasing an additional substrate for LAB activity in the silages they participate, they reduce the silage's content of neutral detergent fibre (NDF), acid detergent fibre (ADF), acid detergent lignin (ADL), hemicellulose and cellulose, and increase dry matter digestibility (DMD) and organic matter digestibility (OMD) (Filya 2001).

This study aimed to determine the effects of lactic acid bacteria+ enzyme $(\mathrm{LAB}+\mathrm{E})$ inoculants addition on the fermentation and in vitro organic matter digestibility characteristics of silages prepared from alfalfa harvested at three maturity stages.

\section{Material and Method}

In this research, alfalfa (Medicago sativa) grown in the experimental areas of the Faculty of Agriculture of Tekirdag Namik Kemal University was used as silage material. Alfalfa was harvested at the early flowering (about $10-20 \%$ bloom), middle flowering (50\% bloom) and late flowering (90-100\% bloom) stage. Alfalfa was wilted to approximately $30 \% \mathrm{DM}$ and chopped to about $1.5-2.0$ $\mathrm{cm}$ length. In the research, commercial inoculant, Sil-All 4x4, (Alltech, UK) (Lactobacillus plantarum, Pediococcus acidilactici, Pediococcus pentosaceus and Propionibacteria acidipropionici bacteria together with amylase, cellulase, xylanase and $\beta$-glucanase enzymes) was used. Inoculant was added to each silage material at the level of $1.0 \times 10^{5}, 5.0 \times 10^{5}$ and $1.0 \times 10^{6} \mathrm{cfu} / \mathrm{g}$. The first group was the control group, and $10 \mathrm{~kg}$ of alfalfa plant was spread on a clean area of $1 \times 4 \mathrm{~m}$, and $20 \mathrm{ml}$ of dechlorinated water was sprayed on it. In the second group, $5 \mathrm{mg}$ of LAB + E inoculant $\left(1.0 \times 10^{5} \mathrm{cfu} / \mathrm{g}\right)$ was weighed and thoroughly mixed with $20 \mathrm{ml}$ of chlorine-free water, and then it was sprayed homogeneously on the shredded clover plant. In group $3,25 \mathrm{mg}$ inoculant $\left(5.0 \times 10^{5} \mathrm{cfu} / \mathrm{g}\right)$, in group 4,50 $\mathrm{mg}$ inoculant $\left(1.0 \times 10^{6} \mathrm{cfu} / \mathrm{g}\right)$ was applied as described in group 2. After thorough mixing, the alfalfa was ensiled in triplicate for each treatment at approximately $500 \mathrm{~g}$ (fresh material), followed in a polythene bag (dimensions $20 \times 25$ $\mathrm{cm}$ ), and sealed by using vacuum packing machine (CAS CVP 260 PD), there were 36 bags ( 3 maturity stage $\times 4$ treatment $\times 3$ replicates) for each treatment. The bags were kept at $20 \pm 2^{\circ} \mathrm{C}$ in laboratory. On the $45^{\text {th }}$ day after ensiling, the bags were opened and chemical and microbiological analyses were performed. The DM contents of the alfalfa silages were determined by drying the samples first at $60^{\circ} \mathrm{C}$ for $72 \mathrm{~h}$ in a forced-ventilation oven (AOAC 1990). In addition, the total nitrogen (TN) was determined using the Kjeldahl method explained in AOAC (1990), and the CP was calculated by multiplying TN by the factor of 6.25 . The ash was determined by incinerating the alfalfa silage content at $600^{\circ} \mathrm{C}$ for 4 hours (AOAC 1990). The alfalfa silage $\mathrm{pH}$ was measured directly from the silage juice using a $\mathrm{pH}$ meter (Inolab, WTW, Germany). Ammonia nitrogen $\left(\mathrm{NH}_{3}-\mathrm{N}\right)$ in the silages was determined by the micro distillation method reported by Anonymous (1986). The content of the WSC in the fresh and silage samples was determined by the antrone-thiourea method reported by the Anonymous (1986) in spectrophotometer (Shimadzu UV-1201, Kyoto, Japan). The LA (Koç and Coskuntuna 2003) contents of silages were determined in the spectrophotometer, while acetic acid (AA) and BA (Supelco 1998) contents were determined in the gas chromatography device. Microbial evaluation included enumeration of lactobacilli on pourplate MRS, and yeast and moulds on spread plate malt extract agar for 3 days at $30^{\circ} \mathrm{C}$ of incubation (Seale 1990). Neutral detergent fibre and ADF analyses were performed according to the methods reported by Goering and Van Soest (1970). in vitro OMD was carried out based on the enzyme method reported by Naumann and Bassler (1993). For this purpose, Pepsin enzyme (Merck, 0.7 FIP-U / g, Germany) and Cellulase enzyme obtained from Trichoderma viride microorganisms (Merck, Onozuka R10; Germany) were used. One-way analysis of variance (ANOVA) was used to evaluate the data obtained from the study, while Duncan multiple comparison test was employed in order to determine significant differences (Soysal 1998). Statistical analyses were performed with SPSS 15.0 (2007) package program.

\section{Results and Discussion}

The results of chemical analysis of alfalfa silages are given in Table 1.

In the study, while $\mathrm{pH}, \mathrm{CP}, \mathrm{NH}_{3}-\mathrm{N}, \mathrm{WSC}$ and $\mathrm{AA}$ contents decreased due to vegetation progression, LA, $\mathrm{NDF}$ and ADF content increased $(\mathrm{P}<0.001)$. The DM and ash were not affected by vegetation period. The DM contents of the silages were between $291.44-322.59 \mathrm{~g} / \mathrm{kg}$, no difference was detected between the silages with $\mathrm{LAB}+\mathrm{E}$ inoculant and the control silage $(\mathrm{P}>0.05)$. 
Table 1. Results of the chemical composition of the alfalfa silages

\begin{tabular}{|c|c|c|c|c|c|c|c|}
\hline Treatment & Maturity & Dose & DM, g/kg & $\mathrm{pH}$ & Ash, g/kg DM & $\mathrm{CP}, \mathrm{g} / \mathrm{kg}$ DM & NDF, g/kg DM \\
\hline 1 & $\mathrm{EF}$ & $\mathrm{C}$ & $306.82^{\mathrm{bc}}$ & $5.18^{\mathrm{a}}$ & 90.37 & $214.40^{\mathrm{a}-\mathrm{d}}$ & $472.37^{\mathrm{d}}$ \\
\hline 2 & $\mathrm{EF}$ & I 1 & $320.31^{\mathrm{a}}$ & $4.92^{\mathrm{bc}}$ & 90.72 & $225.84^{\mathrm{a}}$ & $459.71^{\mathrm{d}}$ \\
\hline 3 & $\mathrm{EF}$ & I 2 & $298.61^{\mathrm{cd}}$ & $5.02^{\mathrm{b}}$ & 93.43 & $225.50^{\mathrm{a}}$ & $469.84^{\mathrm{d}}$ \\
\hline 4 & $\mathrm{EF}$ & I 3 & $307.81^{\mathrm{bc}}$ & $4.91^{\mathrm{bc}}$ & 94.11 & $220.46^{\mathrm{ab}}$ & $467.61^{\mathrm{d}}$ \\
\hline 5 & MF & $\mathrm{C}$ & $297.47^{\mathrm{cd}}$ & $5.20^{\mathrm{a}}$ & 88.67 & $202.36^{\mathrm{d}}$ & $581.22^{\mathrm{a}}$ \\
\hline 6 & MF & I 1 & $291.44^{\mathrm{d}}$ & $4.87^{b c}$ & 90.60 & $217.75^{\mathrm{a}-\mathrm{c}}$ & $558.57^{b}$ \\
\hline 7 & MF & I 2 & $293.18^{d}$ & $4.89^{b c}$ & 93.76 & $210.36^{\mathrm{b}-\mathrm{d}}$ & $561.14^{\mathrm{b}}$ \\
\hline 8 & MF & I 3 & $302.59^{\mathrm{cd}}$ & $4.78^{c}$ & 87.65 & $206.33^{\mathrm{cd}}$ & $522.37^{\mathrm{c}}$ \\
\hline 9 & $\mathrm{LF}$ & $\mathrm{C}$ & $321.78^{a}$ & $4.91^{\mathrm{bc}}$ & 95.58 & $205.77^{\mathrm{cd}}$ & $561.43^{b}$ \\
\hline 10 & $\mathrm{LF}$ & I 1 & $322.59^{a}$ & $4.90^{\mathrm{bc}}$ & 92.39 & $210.11^{\mathrm{b}-\mathrm{d}}$ & $561.99^{b}$ \\
\hline 11 & $\mathrm{LF}$ & I 2 & $316.52^{\mathrm{ab}}$ & $4.87^{\mathrm{bc}}$ & 93.29 & $217.13^{\mathrm{a}-\mathrm{c}}$ & $560.09^{b}$ \\
\hline 12 & LF & I 3 & $317.81^{\mathrm{ab}}$ & $4.79^{c}$ & 94.33 & $206.66^{\mathrm{cd}}$ & $573.30^{\mathrm{ab}}$ \\
\hline \multicolumn{3}{|c|}{$\begin{array}{l}\text { Standard error of mean } \\
\text { Maturity means }\end{array}$} & 3.95 & 0.05 & 2.07 & 3.96 & 6.13 \\
\hline $\mathrm{EF}$ & & & $308.39^{b}$ & $5.01^{\mathrm{a}}$ & 92.16 & $221.55^{a}$ & $467.38^{b}$ \\
\hline $\mathrm{MF}$ & & & $296.17^{c}$ & $4.94^{\mathrm{b}}$ & 90.17 & $209.20^{b}$ & $555.82^{\mathrm{a}}$ \\
\hline LF & & & $319.67^{\mathrm{a}}$ & $4.87^{\mathrm{b}}$ & 93.90 & $209.92^{b}$ & $564.20^{\mathrm{a}}$ \\
\hline \multicolumn{3}{|c|}{$\begin{array}{l}\text { Standard error of mean } \\
\text { Dose means }\end{array}$} & 1.97 & 0.02 & 1.04 & 1.98 & 3.07 \\
\hline $\mathrm{C}$ & & & 308.69 & $5.10^{\mathrm{a}}$ & 91.54 & $207.51^{b}$ & $538.34^{\mathrm{a}}$ \\
\hline I 1 & & & 311.45 & $4.90^{\mathrm{bc}}$ & 91.23 & $217.90^{\mathrm{a}}$ & $526.76^{b}$ \\
\hline I 2 & & & 302.77 & $4.93^{\mathrm{b}}$ & 93.49 & $217.66^{\mathrm{a}}$ & $530.36^{\mathrm{ab}}$ \\
\hline I 3 & & & 309.40 & $4.83^{\mathrm{c}}$ & 92.03 & $211.15^{\mathrm{a}}$ & $521.09^{\mathrm{b}}$ \\
\hline \multicolumn{3}{|c|}{ Standard error of mean } & 2.28 & 0.03 & 1.20 & 2.28 & 3.54 \\
\hline \multicolumn{3}{|c|}{ Maturity (M) } & $<0.001$ & $<0.01$ & 0.057 & $<0.001$ & $<0.001$ \\
\hline \multicolumn{3}{|l|}{ Dose (D) } & 0.070 & $<0.001$ & 0.562 & $<0.01$ & $<0.05$ \\
\hline \multicolumn{3}{|l|}{$M \times D$} & $<0.001$ & $<0.001$ & 0.238 & $<0.01$ & $<0.001$ \\
\hline
\end{tabular}

\begin{tabular}{|c|c|c|c|c|c|c|}
\hline Treatment & $\mathrm{ADF}, \mathrm{g} / \mathrm{kg} \mathrm{DM}$ & $\mathrm{NH}_{3}-\mathrm{N}, \mathrm{g} / \mathrm{kg} \mathrm{TN}$ & WSC, g/kg DM & $\mathrm{LA}, \mathrm{g} / \mathrm{kg} \mathrm{DM}$ & $\mathrm{AA}, \mathrm{g} / \mathrm{kg} \mathrm{DM}$ & $\mathrm{BA}, \mathrm{g} / \mathrm{kg} \mathrm{DM}$ \\
\hline 1 & $403.05^{\mathrm{ef}}$ & $125.63^{\mathrm{a}}$ & $12.37^{\mathrm{b}}$ & $93.80^{\mathrm{bc}}$ & $22.74^{\mathrm{bc}}$ & $0.00^{\mathrm{b}}$ \\
\hline 2 & $380.49^{f g}$ & $101.27^{\mathrm{bc}}$ & $15.98^{\mathrm{a}}$ & $116.37^{\mathrm{a}}$ & $28.32^{\mathrm{ab}}$ & $0.00^{\mathrm{b}}$ \\
\hline 3 & $362.49^{\mathrm{g}}$ & $107.82^{\mathrm{b}}$ & $10.17^{\mathrm{b}}$ & $109.56^{\mathrm{a}}$ & $29.97^{\mathrm{ab}}$ & $0.00^{\mathrm{b}}$ \\
\hline 4 & $338.88^{h}$ & $103.74^{\mathrm{bc}}$ & $3.41^{\mathrm{de}}$ & $112.08^{\mathrm{a}}$ & $34.35^{\mathrm{a}}$ & $0.00^{\mathrm{b}}$ \\
\hline 5 & $479.27^{\mathrm{a}}$ & $111.64^{\mathrm{b}}$ & $3.41^{\mathrm{de}}$ & $91.36^{\mathrm{bc}}$ & $14.05^{\mathrm{cd}}$ & $13.03^{\mathrm{a}}$ \\
\hline 6 & $455.06^{\mathrm{b}}$ & $89.67^{\mathrm{c}-\mathrm{e}}$ & $1.78^{\mathrm{e}}$ & $96.24^{\mathrm{b}}$ & $14.23^{\mathrm{cd}}$ & $16.61^{\mathrm{a}}$ \\
\hline 7 & $415.44^{\mathrm{de}}$ & $98.66^{\mathrm{b}-\mathrm{d}}$ & $2.10^{\mathrm{e}}$ & $110.11^{\mathrm{a}}$ & $12.41^{\mathrm{d}}$ & $14.61^{\mathrm{a}}$ \\
\hline 8 & $392.48^{f}$ & $89.47^{\mathrm{c}-\mathrm{e}}$ & $2.66^{\mathrm{e}}$ & $114.61^{\mathrm{a}}$ & $14.65^{\mathrm{cd}}$ & $14.48^{\mathrm{a}}$ \\
\hline 9 & $397.93^{\text {ef }}$ & $85.43^{\mathrm{d}-\mathrm{f}}$ & $1.86^{\mathrm{e}}$ & $77.00^{\mathrm{d}}$ & $14.33^{\mathrm{cd}}$ & $1.33^{\mathrm{b}}$ \\
\hline 10 & $452.81^{\mathrm{bc}}$ & $77.95^{\mathrm{e}-\mathrm{g}}$ & $6.47^{\mathrm{c}}$ & $83.00^{\mathrm{b}-\mathrm{d}}$ & $13.77^{\mathrm{d}}$ & $1.26^{\mathrm{b}}$ \\
\hline 11 & $447.23^{\mathrm{bc}}$ & $71.83^{\mathrm{fg}}$ & $7.66^{\mathrm{c}}$ & $81.08^{\mathrm{cd}}$ & $14.64^{\mathrm{cd}}$ & $2.10^{\mathrm{b}}$ \\
\hline 12 & $431.48^{\mathrm{cd}}$ & $71.26^{\mathrm{g}}$ & $5.47^{\mathrm{cd}}$ & $82.86^{\mathrm{b}-\mathrm{d}}$ & $12.49^{\mathrm{d}}$ & $2.15^{\mathrm{b}}$ \\
\hline $\begin{array}{l}\text { Standard error of mean } \\
\text { Maturity means }\end{array}$ & 7.15 & 4.47 & 0.79 & 4.37 & 2.66 & 1.92 \\
\hline $\mathrm{EF}$ & $371.23^{b}$ & $109.62^{a}$ & $10.49^{\mathrm{a}}$ & $107.96^{\mathrm{a}}$ & $28.84^{\mathrm{a}}$ & $0.00^{\mathrm{b}}$ \\
\hline MF & $435.56^{\mathrm{a}}$ & $97.36^{\mathrm{b}}$ & $2.49^{c}$ & $103.08^{\mathrm{a}}$ & $13.84^{\mathrm{b}}$ & $14.69^{\mathrm{a}}$ \\
\hline LF & $432.36^{\mathrm{a}}$ & $76.61^{\mathrm{c}}$ & $5.37^{\mathrm{b}}$ & $80.99^{\mathrm{b}}$ & $13.81^{\mathrm{b}}$ & $1.71^{\mathrm{b}}$ \\
\hline $\begin{array}{l}\text { Standard error of mean } \\
\text { Dose means }\end{array}$ & 3.58 & 2.23 & 0.39 & 2.18 & 1.33 & 0.96 \\
\hline $\mathrm{C}$ & $426.75^{\mathrm{a}}$ & $107.56^{\mathrm{a}}$ & $5.88^{\mathrm{b}}$ & $87.39^{b}$ & 17.04 & 4.79 \\
\hline I 1 & $429.45^{\mathrm{a}}$ & $89.63^{b}$ & $8.08^{a}$ & $98.54^{\mathrm{a}}$ & 18.78 & 5.96 \\
\hline I 2 & $408.39^{b}$ & $92.77^{\mathrm{b}}$ & $6.65^{\mathrm{b}}$ & $100.25^{\mathrm{a}}$ & 19.01 & 5.57 \\
\hline I 3 & $387.61^{\mathrm{c}}$ & $88.15^{\mathrm{b}}$ & $3.85^{\mathrm{c}}$ & $103.18^{\mathrm{a}}$ & 20.50 & 5.54 \\
\hline Standard error of mean & 4.13 & 2.58 & 0.45 & 2.52 & 1.53 & 1.11 \\
\hline Maturity (M) & $<0.001$ & $<0.001$ & $<0.001$ & $<0.001$ & $<0.001$ & $<0.001$ \\
\hline Dose (D) & $<0.001$ & $<0.001$ & $<0.001$ & $<0.001$ & 0.479 & 0.899 \\
\hline $\mathrm{M} \times \mathrm{D}$ & $<0.001$ & $<0.001$ & $<0.001$ & $<0.001$ & $<0.001$ & $<0.001$ \\
\hline
\end{tabular}

M: Maturity, D: Dose, EF: Early flowering, MF: Mid flowering, LF: Late flowering, C: Control, I 1: 1x105 cfu/g LAB, I 2: 5x105 cfu/g LAB, I 3: 1x10 cfu/g LAB, DM: Dry matter, CP: Crude protein, NDF: Neutral detergent fiber, ADF: Acid detergent fiber, WSC: Water soluble carbohydrates, NH3$\mathrm{N}$ : Ammonia-nitrogen, TN: Total nitrogen, LA: Lactic acid, AA: Acetic acid, BA: Butyric acid, a-g Within a column means followed by different letter differ significantly $(\mathrm{P}<0.05)$ 
The highest DM content was determined at the late flowering stage $(\mathrm{P}<0.001)$. The ash contents of alfalfa silage were ranged from 87.65 to $95.58 \mathrm{~g} / \mathrm{kg}$ DM but there were no differences between the silage groups (Table 1, $\mathrm{P}>0.05)$. In this study, the $\mathrm{pH}$ values of silages were found between 4.79-5.20 and the highest $\mathrm{pH}$ was determined at the early flowering stage $(\mathrm{P}<0.01)$. The linear decrease in $\mathrm{pH}$ values of alfalfa silages from early to late flowering stage of maturity was in agreement with the findings of Dumlu Gul et al. (2015) and Özduven and Cam Çelebi (2017) who described that $\mathrm{pH}$ values of alfalfa silages decreased with advancing growth of fodder. The $\mathrm{pH}$ values of silages with $\mathrm{LAB}+\mathrm{E}$ inoculant were found to decrease significantly compared to the control silage. Due to the high $\mathrm{CP}$ of the legumes compared to cereals, it slows down the decrease of $\mathrm{pH}$ in fermentation depending on the high buffer capacity (Filya 2005, Dumlu Gul and Tan 2013). This situation was also clearly observed in the current research. Shockey et al. (1985) determined that although LA ingredient of maize silage is nearly two times lower than alfalfa silage, corn silage has lower $\mathrm{pH}$ value. In this study, all of the inoculated silages were better fermented and more successfully ensiled.

Harvesting maturity of alfalfa is highly correlated to its nutritive value (Kaiser and Combs, 1989). The CP contents of alfalfa silage was found to decrease significantly from 221.55 to $209.92 \mathrm{~g} / \mathrm{kg}$ DM at early and full flowering stages, respectively. The reduction of $\mathrm{CP}$ contents with maturity of alfalfa is associated to a decrease of leaves and increase of stems in the forage biomass. The CP contents of the alfalfa silage with all $\mathrm{LAB}+\mathrm{E}$ treatments were higher than that of untreated silage $(\mathrm{P}<0.01)$. The most important activity seen after plant harvest is proteolysis. During this event, proteins in the plant are degraded by protease enzymes into peptides and amides, mainly amino acids and ammonia (Filya 2005). High degradation rates of $\mathrm{CP}$ into silage $\mathrm{NH}_{3}-\mathrm{N}$ contribute usually to increase rumen ammonia concentrations (Givens and Rulquin 2004). Ammonia nitrogen in alfalfa silage has sparked interest as an indicator to evaluate silage quality. The $\mathrm{NH}_{3}-\mathrm{N}$ contents was found to be significantly higher in the silages harvested during the early flowering stage $(\mathrm{P}<0.001)$. This situation may be attributed to the fact that the CP content of silages in the mentioned period is higher in comparison to other maturity stages (Kung et al., 1986, Çerçi et al., 2002). In this study, the $\mathrm{NH}_{3}-\mathrm{N}$ was also recorded as lower in silages treated with $\mathrm{LAB}+\mathrm{E}$ compared to the control silage. It was remarkable that the levels of $\mathrm{NH}_{3}-\mathrm{N}$ in all treated silages were determined to be under the threshold level of $100 \mathrm{~g} / \mathrm{kg}$ TN per good quality silages (McDonald et al., 1988).

The concentration of LA of silages ranged between $77.00-114.61 \mathrm{~g} / \mathrm{kg}$ DM. The LA content of alfalfa silages had a tendency to decrease with the progression of vegetation. On the other hand, $\mathrm{LAB}+\mathrm{E}$ inoculants significantly increased the LA content of silages $(\mathrm{P}<0.001)$. The AA contents of silages were found between $12.41-34.35 \mathrm{~g} / \mathrm{kg} \mathrm{DM}$ in all maturity stages and applications, which is an acceptable range for silages (Luther 1986, Nursoy et al., 2003). The BA content of alfalfa silages in this study are ranged between 0.00-16.61 $\mathrm{g} / \mathrm{kg}$ DM values. While the BA content of alfalfa silages in the mid-flowering stage was significantly higher than other maturity stages $(\mathrm{P}<0.001), \mathrm{LAB}+\mathrm{E}$ inoculant did not affect the $\mathrm{BA}$ content of silages $(\mathrm{P}>0.05)$. Therefore, the treated silage with $\mathrm{LAB}+\mathrm{E}$ was well preserved due to lower $\mathrm{pH}$ and production of a higher amount of LA compared to the control silage. Our study has shown that used LAB+E can improve silage quality and reduce protein degradation in silage. It is precisely the role of inoculants to intensify the production of LA, quickly reduce $\mathrm{pH}$ and prevent the development of pathogenic microorganisms (Nadeau et al., 2000). Li et al. (2018) reported that alfalfa silages treated with $\mathrm{LAB}+\mathrm{E}$ inoculants had significantly lower $\mathrm{pH}$ and $\mathrm{NH}_{3}-\mathrm{N} / \mathrm{TN}$ content, and higher content of LA in comparison with control silage.

The NDF and ADF contents of silages are important quality parameters. A significant increase in NDF and ADF contents of alfalfa silage was observed with advancing stages of maturity $(\mathrm{P}<0.001)$. Canbolat et al. (2006), Yari et al. (2012) and Ozduven and Celebi Cam (2017) reported that NDF and ADF contents were lowest in the flowering stage and highest in the late flowering stage. In the present study, NDF $(\mathrm{P}<0.017)$ and $\mathrm{ADF}(\mathrm{P}<0.001)$ contents (except I1 dose for ADF content) of alfalfa silages with the addition of $\mathrm{LAB}+\mathrm{E}$ in all maturity stages decreased compared to the control silages. This decline in cell wall fractions (ADF and NDF) may have been due to the hydrolytic effect of the fibrolytic enzymes in treated silages. The use of LAB+E inoculants (Chilson et al., 2016, Ozduven and Celebi Cam 2017) lowered the NDF and ADF contents in alfalfa silages. Similar improvements in silage quality following treatment with $\mathrm{LAB}+\mathrm{E}$ inoculants has been reported in other studies (Nadeau et al., 2000, Filya 2002, Polat et al., 2005, Ozduven et al., 2017). Including cell wall degrading enzymes in silage additives has been practise as a means of increasing the contents of WSCs available to LAB, and as a method to degrade cell wall and subsequently improve the digestibility of OM and fiber (Mc Donald et al., 1991, Xing et al., 2009). The WSCs that are released as a result of the breakdown of the cell wall containing the structural carbohydrates of alfalfa were also used as nutrient by lactobacilli. As a result, the alfalfa containing insufficient WSCs for silage fermentation and therefore difficult to ensile was ensiled successfully.

The results of the microbiological analysis of alfalfa silages are given in Table 2 . In the present study, the maturity stages and the use of $\mathrm{LAB}+\mathrm{E}$ inoculant at different levels affected the microbiological compositions of alfalfa silages. As a matter of fact, during the fermentation period, the silages lactobacilli count in the mid flowering stage was found higher than the silages in other maturity stages (Table $2, \mathrm{P}<0.001$ ). In this study, the lactobacilli count of the silages with $\mathrm{LAB}+\mathrm{E}$ inoculant was significantly higher compared to the control silage (Table $2, \mathrm{P}<0.001)$. In contrast, the yeast count of $\mathrm{LAB}+\mathrm{E}$ treated silages decreased compared with the control silage $(\mathrm{P}<0.001)$. In comparison to the control silage, the low $\mathrm{pH}$ levels of silages with $\mathrm{LAB}+\mathrm{E}$ inoculant was a result of increased lactobacilli development and therefore LA production. Similar findings were reported by Koc et al. (2008) and Ozduven and Celebi Cam (2017). In all periods of fermentation, it was found that depending on the dosage used, yeast counts were lower in silages with $L A B+E$ inoculant compared to the control silage $(\mathrm{P}<0.001)$. Silages that are well compressed and with low $\mathrm{pH}$ and oxygen-free environment are not suitable for mold growth (Filya 2005). In fact, none of the silages developed mold. 
Table 2. Results of the microbiological analyses of the alfalfa silages (log cfu/g DM)

\begin{tabular}{|c|c|c|c|c|c|}
\hline Treatment & M & $\mathrm{D}$ & Lactobacilli & Yeast & Mold \\
\hline 1 & $\mathrm{EF}$ & $\mathrm{C}$ & $5.73^{\mathrm{f}}$ & $6.09^{a}$ & ND \\
\hline 2 & $\mathrm{EF}$ & I 1 & $5.82^{e}$ & $5.94^{\mathrm{bc}}$ & ND \\
\hline 3 & $\mathrm{EF}$ & I 2 & $5.94^{\mathrm{d}}$ & $5.86^{\mathrm{de}}$ & ND \\
\hline 4 & $\mathrm{EF}$ & I 3 & $6.04^{c}$ & $5.51^{\mathrm{h}}$ & ND \\
\hline 5 & $\mathrm{MF}$ & $\mathrm{C}$ & $6.04^{c}$ & $6.00^{\mathrm{b}}$ & ND \\
\hline 6 & MF & I 1 & $6.46^{\mathrm{b}}$ & $5.89^{\mathrm{cd}}$ & ND \\
\hline 7 & MF & I 2 & $6.46^{\mathrm{b}}$ & $5.82^{\mathrm{e}}$ & ND \\
\hline 8 & $\mathrm{MF}$ & I 3 & $6.56^{\mathrm{a}}$ & $5.73^{f}$ & ND \\
\hline 9 & $\mathrm{LF}$ & $\mathrm{C}$ & $5.23^{\mathrm{h}}$ & $5.59^{\mathrm{g}}$ & ND \\
\hline 10 & $\mathrm{LF}$ & I 1 & $5.42^{\mathrm{g}}$ & $5.40^{1}$ & ND \\
\hline 11 & LF & I 2 & $5.35^{\mathrm{g}}$ & $5.17^{\mathrm{j}}$ & ND \\
\hline 12 & LF & I 3 & $5.70^{\mathrm{f}}$ & $5.11^{\mathrm{j}}$ & ND \\
\hline \multicolumn{2}{|c|}{$\begin{array}{l}\text { Standard error of mean } \\
\text { Maturity means }\end{array}$} & & 3.95 & 0.05 & \\
\hline $\mathrm{EF}$ & & & $5.89^{b}$ & $5.85^{\mathrm{a}}$ & ND \\
\hline MF & & & $6.38^{a}$ & $5.86^{\mathrm{a}}$ & ND \\
\hline $\mathrm{LF}$ & & & $5.43^{c}$ & $5.32^{b}$ & ND \\
\hline \multicolumn{2}{|c|}{$\begin{array}{l}\text { Standard error of mean } \\
\text { Dose means }\end{array}$} & & 1.97 & 0.02 & \\
\hline $\mathrm{C}$ & & & $5.67^{c}$ & $5.89^{\mathrm{a}}$ & ND \\
\hline I 1 & & & $5.90^{\mathrm{b}}$ & $5.74^{\mathrm{b}}$ & ND \\
\hline I 2 & & & $5.92^{b}$ & $5.61^{\mathrm{c}}$ & ND \\
\hline I 3 & & & $6.10^{\mathrm{a}}$ & $5.45^{\mathrm{d}}$ & ND \\
\hline \multicolumn{3}{|c|}{ Standard error of mean } & 2.28 & 0.03 & \\
\hline \multicolumn{3}{|c|}{ M } & $<0.001$ & $<0.001$ & \\
\hline \multicolumn{3}{|l|}{$\mathrm{D}$} & $<0.001$ & $<0.001$ & \\
\hline & $<0.001$ & $<0.001$ & \\
\hline
\end{tabular}

M: Maturity, D: Dose, EF: Early flowering, MF: Mid flowering, LF: Late flowering, C: Control, I 1: 1x 10 $\mathrm{cfu} / \mathrm{g}$ LAB, I 2: 5x 105 cfu/g LAB, I 3: 1x $10^{6} \mathrm{cfu} / \mathrm{g}$ LAB, ND: Not detected, ${ }^{\mathrm{a}-\mathrm{j}}$ Within a column means followed by different letter differ significantly $(\mathrm{P}<0.05)$

Table 3. Result of the aerobic stability of the alfalfa silages

\begin{tabular}{|c|c|c|c|c|c|c|}
\hline Treatment & $\mathrm{M}$ & $\mathrm{D}$ & $\mathrm{pH}$ & $\mathrm{CO}_{2} \mathrm{~g} / \mathrm{kg} \mathrm{DM}$ & Yeast $\log _{10} \mathrm{cfu} / \mathrm{g}$ DM & Mold $\log _{10} \mathrm{cfu} / \mathrm{g}$ DM \\
\hline 1 & $\mathrm{EF}$ & $\mathrm{C}$ & $5.10^{\mathrm{bc}}$ & $5.65^{\mathrm{d}}$ & $3.51^{\mathrm{d}}$ & ND \\
\hline 2 & $\mathrm{EF}$ & I 1 & $5.10^{\mathrm{bc}}$ & $8.47^{\mathrm{cd}}$ & $4.87^{\mathrm{bc}}$ & ND \\
\hline 3 & $\mathrm{EF}$ & I 2 & $5.34^{\mathrm{a}-\mathrm{c}}$ & $12.92^{\mathrm{c}}$ & $5.32^{\mathrm{a}-\mathrm{c}}$ & ND \\
\hline 4 & $\mathrm{EF}$ & I 3 & $5.57^{\mathrm{a}}$ & $25.25^{\mathrm{b}}$ & $4.83^{\mathrm{c}}$ & ND \\
\hline 5 & MF & $\mathrm{C}$ & $5.14^{\mathrm{bc}}$ & $4.25^{\mathrm{d}}$ & $1.52^{\mathrm{f}}$ & ND \\
\hline 6 & MF & I 1 & $5.06^{\mathrm{bc}}$ & $4.02^{\mathrm{d}}$ & $1.87^{\mathrm{f}}$ & ND \\
\hline 7 & MF & I 2 & $5.39^{\mathrm{ab}}$ & $5.68^{d}$ & $2.73^{\mathrm{e}}$ & ND \\
\hline 8 & MF & I 3 & $5.09^{\mathrm{bc}}$ & $3.40^{\mathrm{d}}$ & $2.53^{\mathrm{e}}$ & ND \\
\hline 9 & $\mathrm{LF}$ & $\mathrm{C}$ & $5.08^{\mathrm{bc}}$ & $25.40^{\mathrm{b}}$ & $5.24^{\mathrm{a}-\mathrm{c}}$ & ND \\
\hline 10 & $\mathrm{LF}$ & I 1 & $5.23^{\mathrm{a}-\mathrm{c}}$ & $39.29^{\mathrm{a}}$ & $5.39^{\mathrm{ab}}$ & ND \\
\hline 11 & $\mathrm{LF}$ & I 2 & $4.98^{c}$ & $25.34^{\mathrm{b}}$ & $5.57^{\mathrm{a}}$ & ND \\
\hline 12 & LF & I 3 & $5.04^{\mathrm{bc}}$ & $27.04^{\mathrm{b}}$ & $5.35^{\mathrm{a}-\mathrm{c}}$ & ND \\
\hline \multicolumn{3}{|c|}{$\begin{array}{l}\text { Standard error of mean } \\
\text { Maturity means }\end{array}$} & 0,11 & 2,15 & 0.16 & - \\
\hline \multicolumn{3}{|c|}{\begin{tabular}{|l|l}
$\mathrm{EF}$ &
\end{tabular}} & 5.28 & $13.07^{b}$ & $4.63^{b}$ & ND \\
\hline MF & & & 5.17 & $4.34^{\mathrm{c}}$ & $2.16^{\mathrm{c}}$ & ND \\
\hline $\mathrm{LF}$ & & & 5.08 & $29.27^{\mathrm{a}}$ & $5.38^{\mathrm{a}}$ & ND \\
\hline \multicolumn{3}{|c|}{$\begin{array}{l}\text { Standard error of mean } \\
\text { Dose means }\end{array}$} & 0,06 & 1,08 & 0.08 & - \\
\hline $\mathrm{C}$ & & & 5.11 & $11.77^{\mathrm{c}}$ & $3.42^{\mathrm{c}}$ & ND \\
\hline I 1 & & & 5.13 & $17.26^{\mathrm{ab}}$ & $4.04^{\mathrm{b}}$ & ND \\
\hline I 2 & & & 5.24 & $14.65^{b}$ & $4.54^{\mathrm{a}}$ & ND \\
\hline I 3 & & & 5.24 & $18.56^{\mathrm{a}}$ & $4.24^{\mathrm{b}}$ & ND \\
\hline \multicolumn{3}{|c|}{ Standard error of mean } & 0,07 & 1.24 & 0.09 & - \\
\hline \multicolumn{3}{|c|}{ M } & 0.068 & $<0.001$ & $<0.001$ & - \\
\hline \multicolumn{3}{|l|}{$\mathrm{D}$} & 0.371 & 0.004 & $<0.001$ & - \\
\hline \multicolumn{3}{|l|}{$M * D$} & 0.037 & $<0.001$ & $<0.001$ & - \\
\hline
\end{tabular}

M: Maturity, D: Dose, EF: Early flowering, MF: Mid flowering, LF: Late flowering, C: Control, I 1: 1x 10 $0^{5} \mathrm{cfu} / \mathrm{g}$ LAB, I 2: 5x 10 cfu/g LAB, I 3: 1x $10^{6} \mathrm{cfu} / \mathrm{g} \mathrm{LAB}, \mathrm{ND}$ : Not detected, ${ }^{\mathrm{a}-\mathrm{j}}$ Within a column means followed by different letter differ significantly $(\mathrm{P}<0.05)$ 
The impact of $\mathrm{LAB}+\mathrm{E}$ treatment on the aerobic stability of alfalfa silages after exposure to air for five days is shown in Table 3. Aerobic deterioration of silage is a complex process which depends on many factors. Usually, it is initiated by aerobic yeasts that can use either residual WSCs or LA for their metabolism. Aerobic deterioration usually results in production of $\mathrm{CO}_{2}$ (Weinberg et al., 2001). In the present study, the $\mathrm{LAB}+\mathrm{E}$ treated silages had higher $\mathrm{CO}_{2}$ production and the yeast counts as compared with control silages $(\mathrm{P}<0.001)$. Treatment with $\mathrm{LAB}+\mathrm{E}$ mixture had high contents of residual WSCs and LA and therefore, tended to spoil more upon aerobic exposure, as indicated by more intensive $\mathrm{CO}_{2}$ production. These results were consistent with those of Chen et al. (1994) who reported reduced aerobic stability with a $\mathrm{LAB}+\mathrm{E}$ addition in maize silage. Furthermore, there was a slight increase detected in $\mathrm{pH}$ values of alfalfa during that 5-day period when silage deterioration occurred.
The ME and in vitro OMD values were higher $(\mathrm{P}<0.001)$ observed between the maturity and the treatments (Table 4). However, the in vitro OMD and ME values at the early flowering stage were higher compared to the mid and full flowering stages $(\mathrm{P}<0.001)$. The in vitro $\mathrm{OMD}$ and $\mathrm{ME}$ values in all $\mathrm{LAB}+\mathrm{E}$ treated silages were found higher compared to control silage $(\mathrm{P}<0.001)$.

Ozduven et al. (2017) suggested that a decrease in NDF and $\mathrm{ADF}$ in silage materials could increase the in vitro $\mathrm{OMD}$ of $\mathrm{LAB}+\mathrm{E}$ inoculants treated silage. In the present study, lower NDF and ADF contents determined for all $\mathrm{LAB}+\mathrm{E}$ treated silages may also indicate the improved quality of silage fermentation in terms of in vitro OMD of silages. The findings obtained in the study on silages in vitro $\mathrm{OMD}$ are consistent with the findings from previous studies (Ozduven et al., 2009, Denek et al., 2012, Sucu and Aydogan Ciftci 2016).

Table 4. Result of the OMD and ME values of the alfalfa silages

\begin{tabular}{|c|c|c|c|c|}
\hline Treatment & $\mathrm{M}$ & $\mathrm{D}$ & OMD, g/kg DM & $\mathrm{ME}, \mathrm{MJ} / \mathrm{kg} \mathrm{DM}$ \\
\hline 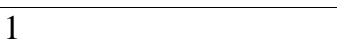 & $\mathrm{EF}$ & $\mathrm{C}$ & $607.15^{\mathrm{b}}$ & $8.73^{\mathrm{b}}$ \\
\hline 2 & $\mathrm{EF}$ & I 1 & $612.02^{\mathrm{b}}$ & $8.81^{\mathrm{b}}$ \\
\hline 3 & $\mathrm{EF}$ & I 2 & $608.79^{b}$ & $8.73^{b}$ \\
\hline 4 & $\mathrm{EF}$ & I 3 & $644.50^{\mathrm{a}}$ & $9.14^{\mathrm{a}}$ \\
\hline 5 & MF & $\mathrm{C}$ & $521.07^{\mathrm{e}}$ & $7.69^{\mathrm{e}}$ \\
\hline 6 & $\mathrm{MF}$ & I 1 & $551.19^{\mathrm{cd}}$ & $8.06^{\mathrm{c}}$ \\
\hline 7 & MF & I 2 & $540.41^{\mathrm{d}}$ & $7.87^{\mathrm{d}}$ \\
\hline 8 & MF & I 3 & $558.26^{\mathrm{c}}$ & $8.16^{\mathrm{c}}$ \\
\hline 9 & $\mathrm{LF}$ & $\mathrm{C}$ & $487.33^{\mathrm{h}}$ & $7.19^{\mathrm{g}}$ \\
\hline 10 & $\mathrm{LF}$ & I 1 & $489.50^{\mathrm{g}}$ & $7.39^{f}$ \\
\hline 11 & $\mathrm{LF}$ & I 2 & $505.04^{\mathrm{fg}}$ & $7.47^{\mathrm{f}}$ \\
\hline 12 & $\mathrm{LF}$ & I 3 & $510.03^{\mathrm{f}}$ & $7.49^{f}$ \\
\hline $\begin{array}{l}\text { Standard error of mean } \\
\text { Maturity means }\end{array}$ & & & 3.72 & 0.05 \\
\hline $\mathrm{EF}$ & & & $618.11^{\mathrm{a}}$ & $8.85^{\mathrm{a}}$ \\
\hline MF & & & $542.73^{\mathrm{b}}$ & $7.95^{\mathrm{b}}$ \\
\hline $\mathrm{LF}$ & & & $500.22^{c}$ & $7.38^{\mathrm{c}}$ \\
\hline $\begin{array}{l}\text { Standard error of mean } \\
\text { Dose means }\end{array}$ & & & 1.86 & 0.03 \\
\hline $\mathrm{C}$ & & & $538.51^{\mathrm{c}}$ & $7.87^{\mathrm{c}}$ \\
\hline I 1 & & & $553.90^{\mathrm{b}}$ & $8.09^{b}$ \\
\hline I 2 & & & $551.41^{\mathrm{b}}$ & $8.02^{\mathrm{b}}$ \\
\hline I 3 & & & $570.93^{\mathrm{a}}$ & $8.26^{\mathrm{a}}$ \\
\hline Standard error of mean & & & 2.15 & 0.03 \\
\hline M & & & $<0.001$ & $<0.001$ \\
\hline $\mathrm{D}$ & & & $<0.001$ & $<0.001$ \\
\hline$M * D$ & & & $<0.001$ & $<0.001$ \\
\hline
\end{tabular}

M: Maturity, D: Dose, EF: Early flowering, MF: Mid flowering, LF: Late flowering, C: Control, I 1: 1x105 cfu/g LAB, I 2: 5x105 cfu/g LAB, I 3: 1x10 cfu/g LAB, DM: Dry matter, OMD: Organic matter digestibility, ME: Metabolic energy, ${ }^{\mathrm{a}-\mathrm{g}}$ Within a column means followed by different letter differ significantly $(\mathrm{P}<0.05)$

\section{Conclusion}

From the perspective of feed value, fermentation characteristics and in vitro OMD of alfalfa silage, alfalfa harvested at early flowering stage were more suitable for ensiling. The results showed that $\mathrm{LAB}+\mathrm{E}$ inoculants reduced $\mathrm{pH}$ values and $\mathrm{NH}_{3}-\mathrm{N}$ content, whereas increased LA contents and lactobacillus count of alfalfa silages. High doses $\mathrm{LAB}+\mathrm{E}$ inoculant decreased NDF and ADF content, increased in vitro OMD of alfalfa silages. It has been demonstrated that the most effective application dose of $\mathrm{LAB}+\mathrm{E}$ inoculant to improve fermentation and feed value of alfalfa silage was $1 \times 10^{6} \mathrm{cfu} / \mathrm{g}$, but $1 \times 10^{5}$ and $5 \times 10^{5} \mathrm{cfu} / \mathrm{g}$ level can also be considered as effective dose.

\section{References}

Acar Z, Bostan M. 2016. Değişik doğal katkı maddelerinin yonca silajının kalitesine etkilerinin belirlenmesi. Anadolu Tarım Bilimleri Dergisi, 31:433-440.

Anonymous 1986. The Analysis of Agricultural Material, Reference Book: pp. 427-428, London. 
AOAC, 1990. Official Methods of Analysis. 15 th ed., Association of Official Analytical Chemists. Arlington. Virginia. USA.

Canbolat Ö. 2013. Farklı olgunlaşma dönemlerinin kolza otunun (Brassica napus L.) potansiyel besleme değeri üzerine etkisi. Ankara Üniversitesi Veteriner Fakültesi Dergisi, 60:145-150.

Canbolat O, Kamalak A, Ozkan CO, Erol A, Sahin M, Karakas E and Ozkose E. 2006. Prediction of relative feed value of alfalfa hays harvested at different maturity stages using in vitro gas production. Livestock Research for Rural Development, Volume 18(2):

Chen J, Stokes MR, Wallace CR. 1994. Effects of Enzyme Inoculant Systems on Preservation and Nutritive Value of Hay Crop and Corn Silages. Journal Dairy Science, 77:501-512.

Chilson JM, Rezamand P, Drewnoski ME, Price W, Hunt CW. 2016. Effect of homofermentative lactic acid bacteria and exogenous hydrolytic enzymes on the ensiling characteristics and rumen degradability of alfalfa and corn silages. The Professional Animal Scientist, 32:598-604.

Çerçi İ H, Tatlı P, Gürdoğan F, Birben N. 2002. Farklı vejetasyon dönemlerinde hasat edilen mısıra üre katkısının silaj kalitesi ve toklularda besin maddelerinin sindirilebilirliği üzerine etkisi. The Turkish Journal of Veterinary and Animal Sciences, 26:479-485.

Çerçi İH, Şahin K, Güler T. 1996. Farklı Oranlarda Silajlık Misır Yonca Kullanılarak Yapılan Silajların Kalitesinin Belirlenmesi. Fırat Üniversitesi Sağlık Bilimleri Dergisi, 10(2): 193-200.

Çiftçi M, Çerçi H, Dalkılıç B, Güler T, Ertas ON. 2005. Elmanın karbonhidrat kaynağı olarak yonca silajına katılma olanağının araştırılması. Yüzüncü Yıl Üniversitesi Veteriner Fakültesi Dergisi, 16(2):93-98.

Denek N, Can A, Avc1 M, Aksu T. 2012. The Effect of Fresh and Frozen Pre-Fermented Juice on the Fermentation Quality of Alfalfa Silage. Kafkas Üniversitesi Veteriner Fakültesi Dergisi, 18(5): 785-790.

Dumlu Gül Z, Tan M. 2013. Baklagil Yem Bitkilerinin Silajlık Olarak Kullanılması. Atatürk Üniversitesi Ziraat Fakültesi Dergisi, 44 (1): 189-193.

Filya İ. 2001. Silaj Teknolojisi. Uludağ Üniversitesi Ziraat Fakültesi Zootekni Bölümü, 16059, Görükle, Bursa.

Filya İ. 2002. Laktik asit bakteri ve laktik asit bakteri+enzim karışımı silaj inokulantlarının mısır silajı üzerine etkileri. The Turkish Journal of Veterinary and Animal Sciences, 26:679-687.

Filya İ. 2005. Silaj yapımı, teknolojisi ve kullanımı. Sütaş Hayvancilık Serisi:8, Bursa.

Givens DI, Rulquin H. 2004. Utilisation by ruminants of nitrogen compounds in silage-based diets. Animal Feed Science and Technology, 114:1-18.

Goering HK, Van Soest PJ. 1970. Forage Fiber Analyses (Apparatus, Reagents, Procedures and Some Applications). Agricultural Handbook, No. 379, U.S. Government Printing Office, Washington, DC.

Kaiser RM, Comb DK. 1989. Utilization of Three Maturities of Alfalfa by Dairy Cows Fed Rations that Contain Similar Concentrations of Fiber. Journal of Dairy Science, 72(9): 2301-2307.

Koç F, Coskuntuna L. 2003. Silo Yemlerinde Organik Asit Belirlemedeki İki Farklı Metodun Karşılaştırılması. Journal of Animal Production, 44(2): 37-47.

Koc F, Coskuntuna L, Ozduven ML. 2008. The effect of bacteria+ enzyme mixture silage inoculant on the fermentation characteristic, cell wall contents and aerobic stabilities of maize silage. Pakistan Journal of Animal Science, 7(2): 222-226.

Kung JL, Craig VM, Satter LD, Broderick GA. 1986. Effect of adding formaldehyde, glutaraldehyde or dimethylourea to alfalfa before ensiling. Journal Dairy Science, 69:2846-2854.

Li D, Ni K, Zhang Y, Lin Y, Yang F. 2018. Influence of lactic acid bacteria, cellulase, celullase-producing Bacillus pumilus and their combinations on alfalfa silage quality. Journal of Integrative Agriculture, 17:2768-2782.
Luther MR. 1986. Effect of microbial inoculation of whole plant corn silage on chemical characteristics. Preservation and utilization by steers. The Journal of Animal Science, (1):6773.

McDonald P, Edwards RA, Greenhalgh JFD. 1988. Animal Nutrition. 4th Edition. Longman Scientific and Technical, $543 \mathrm{p}$.

Nadeau EMG, Russell JR, Buxton DR. 2000. Intake, Digestibility, and Composition of Orchardgrass and Alfalfa Silages Treated with Cellulase, Inoculant, and Formic Acid Fed to Lambs. The Journal of Animal Science, 78:2980-2989.

Naumann C, Bassler R. 1993. Die Chemische Untersuchung von Futtermitteln. VDLUFA-Methodenbuch, Band III. 3. Erg., Verlag Naumann, Melsungen.

Nesic Z, Tomic Z, Zujovic M, Krinjaja V. 2005. Production characteristics of domestic alfalfa (Medicago sativa L.) cultivars in agroecological conditions of Srem district. Biotechnology in Animal Husbandry, 21(5-6):169-173.

Nursoy H, Deniz S, Demirel M, Denek N. 2003. Süt olum döneminde biçilen kimi mısır hasıllarına üre ve melas katkılarının silaj kalitesi ile sindirilebilir kuru madde verimine etkisi. The Turkish Journal of Veterinary and Animal Sciences, 27:93-99.

Oktay E, Olgun H, Ünal S. 1990. Çeşitli koşullarda kurutulan yoncanın besin değeri kaybı üzerine bir araştırma. Lalahan Hayvancılık Araştırma Enstitüsü Dergisi, 35-45.

Ozduven ML, Celebi Cam A. 2017. The Effects of Bacterial Inoculants and/or Enzymes on the Fermentation Characteristics and Aerobic Stability of Alfalfa Ensiled at Different Stages of Maturity. International Journal of Current Research, 9(02):45983-45988.

Ozduven ML, Koc F, Polat C, Coskuntuna L. 2009. The effects of lactic acid bacteria and enzyme mixture inoculants on fermentation and nutrient digestibility of sunflower silage. The Journal of the Faculty of Veterinary Medicine University of Kafkas, 15(2): 195-199.

Ozduven ML, Okuyucu B, Büyükkiliç Beyzi S, Konca Y. 2017. The effects of lactic acid bacterial inoculants on the fermentation, aerobic stability and nutritive value of sunflower silages. International Journal of Current Research, 9(7):54289-54295.

Oten M, Kiremitci S, Cinar O. 2016. Bazı yem bitkileri ve karışımlarıyla hazırlanan silajların silaj kalitelerinin farklı yöntemlerle belirlenmesi. Anadolu, 26(2):33-43.

Polat C, Koç F, Özdüven ML. 2005. Mısır silajlarnda laktik asit bakterileri ve laktik asit bakteri+enzim karışımı inokulantların fermantasyon ve toklularda ham besin maddelerinin sindirilme dereceleri üzerine etkileri. Journal of Tekirdag Agricultural Faculty, 2: 13-22.

Radovic J, Sokolovic D, and Markovic J. 2009. Alfalfa- most important perennial forage legume in Animal Husbandry. Average alfalfa yield in second and third year of utilization. Biotechnology in Animal Husbandry, 25(5-6): 465-475.

Seale DR, Pahlow G, Spoelstra SF, Lindgren S, Dellaglio F, Lowe JF. 1990. Methods for The Microbiological Analysis of Silage, Proceeding of The Eurobac Conference, 147. Uppsala.

Shockey WL, Dehority BA, Conrad HR. 1985. Effects of microbial inoculant on fermentation of alfalfa and corn. Journal of Dairy Science, 68: 3076-3080.

Soysal Mİ, 1998. Biyometrinin Prensipleri (İstatistik I ve II Ders Notları), Yayın No:95, Ders Kitabı No: 64, T.Ü. Tekirdağ Ziraat Fakültesi, s.331, Tekirdağ.

SPSS, 2007. SPSS 15 for Windows. SPSS Inc.

Sucu E, Aydogan Cifci E. 2016. Effects of lines and inoculants on nutritive value and production costs of triticale silages. Revista Brasileira de Zootecnia, 45(7):355-364.

Supelco 1998. Analyzing fatty acids by packed column gas chromatography. Bulletin 856B. Sigma Aldrich, St. Louis, MO. 
Weinberg ZG, Szakacs G, Ashbell G, Hen Y. 2001. The effect of temperature on the ensiling process of corn and wheat. Journal of Applied Microbiology, 90: 561-566.

Xing L, Chen J, Han LJ. 2009. The effect of an inoculant and enzymes on fermentation and nutritive value of sorghum straw silages. Bioresource Technology, 100: 488-491.
Yari M, Valizadeha R, Naseriana AA, Ghorbani GR, Rezvani Moghaddam P, Jonker A, Yue P. 2012. Botanical traits, protein and carbohydrate fractions, ruminal degradability and energy contents of alfalfa hay harvested at three stages of maturity and in the afternoon and morning. Animal Feed Science and Technology, 192: 62-72.

Zubair HM, Pratley JE, Sandral GA, Humphries A. 2017. Allelopathic interference of alfalfa (Medicago sativa L.) genotypes to annual ryegrass (Lolium rigidum). The Journal of Plant Research, 130:647-658. 